MATEUSZ WRONA

ORCID: 0000-0002-1236-5459

Uniwersytet Wroclawski

\title{
Osoby nieheteroseksualne jako konsumenci
}

DOI: $10.19195 / 2083-7763.9 .5$

\section{Wstęp}

Zachowania konsumenckie mieszczą się w zakresie zainteresowania więcej niż jednej dyscypliny naukowej. Modele zachowań konsumenckich wskazują, że na zachowania konsumenckie mają wpływ nie tylko czynniki ekonomiczne, lecz także społeczno-kulturowe. Analizując czynniki społeczne, należy wyszczególnić płeć i wiek konsumenta, a także tożsamość seksualną, czyli samoidentyfikację jednostki. Na podstawie tego czynnika niektórzy producenci czy usługodawcy dokonują segmentacji rynku, kierując swoje produkty do kategorii społecznej osób nieheteroseksualnych. Grupa tych konsumentów została również zauważona przez marketingowców, którzy używają do jej określenia pojęcia DINK.

Celem artykułu jest wykazanie, że kategoria społeczna osób nieheteroseksualnych może być traktowana jako oddzielny segment konsumentów. W związku z tym przeprowadzona zostanie krótka charakterystyka tej grupy, podkreślona zostanie jej siła nabywcza oraz determinanty wpływające na decyzje zakupowe jej członków. Opracowanie powstało na podstawie analizy danych zastanych.

W tekście wykazana zostanie różnica pomiędzy orientacją seksualną a tożsamością seksualną. Wpływ na zachowania konsumentów nieheteroseksualnych mają aspekty wykluczenia czy dyskryminacji tych osób ze względu na nieheteronormatywną tożsamość seksualną. Zwrócona zostanie również uwaga, że środowisko osób nieheteroseksualnych nie jest homogeniczne, a także podkreślone zostaną różnice w zachowaniach konsumenckich między lesbijkami a gejami oraz dyferencje w podejściu do reklamy.

Zauważalny jest trend wdrażania nowej strategii marketingowej nazywanej strategią równości. Opisana zatem zostanie strategia gay-friendly ze wskazaniem przykładów prawidłowego oraz nieprawidłowego jej wykorzystywania. 


\section{Seksualność a rynek}

Seksualnośćczłowieka jest przyczyną wielu dyskusji w kręgach badaczy różnych dyscyplin naukowych. $Z$ jednej strony wydawać by się mogło, że problem ten może dotyczyć tylko badaczy zajmujących się seksuologią czy psychologią, jest to jednak bardzo krótkowzroczne spojrzenie na zagadnienie seksualności człowieka. Należy zauważyć, że seksualność jest pojęciem bardzo szerokim, dotyczy ono nie tylko aspektów psychologicznych, lecz także społecznych czy zdrowotnych. Seksualność człowieka należy traktować jako konstrukt społeczny, ponieważ zarówno określa ona zaangażowanie seksualne czy emocjonalne jednostki, jak i buduje jej tożsamość, a co za tym idzie - jej odbiór przez społeczeństwo.

Tworzenie indywidualnej tożsamości seksualnej jest najłatwiejsze, gdy jednostka dokonuje samoidentyfikacji jako osoba heteroseksualna. Komunikuje ona swoją tożsamość poprzez naturalne - z perspektywy społeczeństwa - rozmowy na temat zainteresowania płcią przeciwną, podziwiania jej fizyczności lub też rozmowy na temat własnych doświadczeń romantycznych, emocjonalnych czy seksualnych ${ }^{1}$. Nikogo nie dziwi, gdy mężczyzna opowiada o doświadczeniach emocjonalnych związanych z kobietami. Zupełnie innej reakcji może spodziewać się osoba identyfikująca się jako nieheteroseksualna. Ze względu na stereotypy może ona mieć problemy ze społeczną akceptacją swojej tożsamości.

Należy zauważyć, że w polskiej literaturze pojęcie tożsamości seksualnej nie jest powszechne. Zdarza się, że jest ono stosowane zamiennie $\mathrm{z}$ określeniem orientacji seksualnej. Porównując jednak te dwa pojęcia, można zauważyć, że istnieje między nimi znaczna różnica. Pojęcie tożsamości seksualnej jest subiektywne ${ }^{2}$, określane przez jednostkę, natomiast orientacja seksualna jest obiektywnie zmierzona różnego rodzaju narzędziami, na przykład skalą Kinseya ${ }^{3}$. Tożsamość seksualna jednostki jest oparta na samoidentyfikacji. Nie jest ona mierzona obiektywnymi narzędziami, jest wyłącznie subiektywną opinią jednostki na temat przynależności do jednej z kategorii społecznych: osób heteroseksualnych lub nieheteroseksualnych.

Najbardziej popularną miarą orientacji seksualnej jest skala Kinseya. Stosuje się ją do pomiaru orientacji na podstawie kontinuum seksualnego — od „wyłącznie heteroseksualny” do „wyłącznie homoseksualny”4.

1 S. Seidman, Społeczne tworzenie seksualności, przeł. P. Tomanek, Warszawa 2012, s. 102.

2 J. Bancroft, Seksualność człowieka, przeł. R. Śmietana, Wrocław 2012, s. 271.

3 Autor reprezentuje pogląd, że w badaniach społecznych należy używać pojęcia „tożsamość seksualna" - jest to ocena subiektywna. Jeżeli badacz zdecyduje się grupować respondentów na podstawie orientacji seksualnej, musi dokonać jej pomiaru. Nie ma możliwości zapytania respondenta o jego orientację seksualną, ponieważ nie jest ona subiektywną oceną respondenta, lecz obiektywnym pomiarem na podstawie odpowiednich narzędzi, na przykład skali Kinseya.

4 A.C. Kinsey, W.B. Pomeroy, C.E. Martin, Sexual Behavior in the Human Male, Philadelphia-London 1948, s. 656. 
Na rynku dóbr i usług coraz częściej można dostrzec nowy segment klientów - klientów nieheteroseksualnych. Pojawiają się firmy oferujące produkty skierowane do osób nieheteroseksualnych: powstają portale randkowe dla gejów, lesbijek, biura podróży dla osób nieheteroseksualnych, gazety, czasopisma. Zmiany na rynku dóbr i usług to nie tylko tworzenie nowych firm mających za grupę docelową osoby nieheteroseksualne, lecz także wprowadzanie nowych produktów znanych firm, skierowanych do tej grupy konsumentów. W 2008 roku szwedzki producent wódki - firma Absolut - wyprodukował alkohol Absolut Colors. Butelka trunku była opatrzona kolorami tęczowej flagi na znak upamiętnienia trzydziestolecia tego symbolu.

Największym rynkiem, który kieruje swoje usługi do klientów nieheteroseksualnych, jest rynek turystyczny. Można znaleźć na przykład hotele, linie lotnicze, biura podróży określające się jako gay-friendly. Firmy te w swoich logotypach lub w ich bliskiej odległości umieszczają znak tęczowej flagi - symbolu osób nieheteroseksualnych.

\section{Identyfikacja jednostki a tworzenie nowej kategorii społecznej}

Głównym motorem tożsamości jednostki jest samoidentyfikacja. W trakcie identyfikacji jednostka dokonuje porównania siebie do innych uczestników życia społecznego. Gdy odnajdzie wspólne cele z innymi jednostkami, może dojść do stworzenia nowej grupy społecznej — osób o tożsamości homoseksualnej, heteroseksualnej czy biseksualnej. Dużo częściej dochodzi do tworzenia się takich środowisk wśród osób nieheteroseksualnych niż heteroseksualnych. Jest to związane z chęcią poznania osób podobnych do siebie oraz spędzenia czasu w grupie, która nie określa jednostki wyłącznie poprzez tożsamość seksualną. Znacznie łatwiej dokonać swojej identyfikacji w dużych aglomeracjach miejskich, natomiast problem z samoidentyfikacją pojawia się w małych zbiorowiskach — w szczególności wiejskich, w których stopień anonimowości jest mały.

Lata 60.-70. ubiegłego wieku miały wielki wpływ na budowanie tożsamości gejowskiej, lesbijskiej czy ogólnie mówiąc - tożsamości osób nieheteroseksualnych (LGBT) ${ }^{5}$. Rewolucja seksualna nie tylko doprowadziła do większej otwartości społeczeństwa, zwiększenia praw kobiet i osób nieheteroseksualnych, lecz

${ }^{5}$ Według autora w języku polskim należy używać określenia „nieheteroseksualny” z racji tego, że opisuje ono wszystkie jednostki, które identyfikują się inaczej niż heteroseksualiści. Określenie LGBT (lesbian, gay, bisexual, transgender) odnosi się tylko do czterech wymienionych kategorii. Dodatkowo akronim ten cały czas się rozrasta poprzez dodawanie nowych liter określających osoby identyfikujące się z inną, niewymienioną jeszcze, tożsamością seksualną, płciową lub jako sprzymierzeńcy tej kategorii społecznej. 
także miała wpływ na dyskusje związane $\mathrm{z}$ tematem identyfikacji płciowej ${ }^{6}-$ ukazała potencjał kategorii osób nieheteroseksualnych.

Badania Alfreda Kinseya z roku 1948 wykazały, że w grupie wiekowej 16-55 lat $4 \%$ amerykańskich mężczyzn przez całe życie, licząc od momentu rozpoczęcia dojrzewania, było „wyłącznie homoseksualnych”7. W zależności od badania procent osób nieheteroseksualnych jest różny. Jest to związane z metodologią badania, a także z samymi respondentami. Ze względu na powszechne stereotypy związane z osobami nieheteroseksualnymi może dojść do ryzyka, że respondent, choć będzie identyfikował się jako osoba nieheteroseksualna, z chęci bycia lepiej odebranym wskaże, że jest osobą heteroseksualną.

Na podstawie danych należy skonstatować, że $4 \%$ społeczeństwa to grupa konsumentów, których rynek nie może zlekceważyć ${ }^{8}$. Biorąc pod uwagę, że osoby nieheteroseksualne starają się spędzać wolny czas w gronie osób związanych ze środowiskiem mniejszości seksualnych, tworząc zamknięte społeczności, można dedukować, że ich zachowania konsumenckie są inne niż osób heteroseksualnych. Wpływ na różnice w zachowaniach konsumenckich ma wykluczenie społeczne czy homofobia. Osoby nieheteroseksualne już od lat 60 . XX wieku tworzyły swojego rodzaju społeczności, które walczyły o prawa mniejszości seksualnych. Tego rodzaju grupy społeczne są ukierunkowane na konkretny cel — od walki o równość po wspólne spędzanie czasu. Dodatkowym aspektem jest brak lub mniejsze prawdopodobieństwo posiadania dzieci. W takich wypadkach jednostka może dokonać transferu swojego potencjału na inne aspekty życia, na przykład edukacji.

\section{Osoba nieheteroseksualna jako konsument}

W dotychczasowych rozważaniach wykazano różnicę między tożsamością seksualną a orientacją seksualną. Wskazano również cele tworzenia się grup społecznych składających się z osób nieheteroseksualnych. Ale kim jest konsument nieheteroseksualny? ${ }^{9}$

Chociaż może się to wydawać dyskryminujące, badacze skupiają się częściej na kategorii mężczyzn nieheteroseksualnych aniżeli kobiet. Może to być spowodowane tym, że są oni bardziej dostrzegani przez społeczeństwo lub też

6 J. Escoffier, The Sexual Revolution, s. 1, http://www.glbtqarchive.com/ssh/sexual_revolution_S.pdf (dostęp: 28.10.2018).

7 A.C. Kinsey, W.B. Pomeroy, C.E. Martin, op. cit., s. 651.

8 Więcej informacji na temat populacji osób nieheteroseksualnych można znaleźć w artykule G.J. Gates, How many people are lesbian, gay, bisexual, and trandgender?, The Williams Institute, 2011.

9 O zachowaniach polskiego konsumenta nieheteroseksualnego więcej można przeczytać w badaniach Jacka Borzyszkowskiego oraz Adriana Lubowieckiego-Vikuka Travel destinations of Polish LGBT community. Przeprowadzili oni badania na grupie 442 respondentów, tematem badania były destynacje wyjazdowe. Warta polecenia jest również pozycja Pink Tourism. Holidays of Gay Men and Lesbians Howarda L. Hughesa (Walingford 2006). 
wywołują większe poruszenie swoją obecnością. Dodatkowo to mężczyźni rzadziej decydują się na posiadanie dziecka, co znacznie wpływa na ich budżet domowy. Na podstawie badań Gallup Daily Tracking Survey 2012 oraz American Community Survey 2011można szacować, że 27,4\% kobiet będących w związku jednopłciowym wychowuje dziecko w porównaniu do 10,6\% mężczyzn w związkach jednopłciowych ${ }^{10}$.

Posiadanie dzieci może być jedną $\mathrm{z}$ determinant różnicujących zachowania konsumenckie gejów i lesbijek. Jak pokazują badania, kategorie te mają inne potrzeby i zaspokajają je w różny sposób. Community Marketing w 2002-2003 roku w Stanach Zjednoczonych przeprowadziło badania, z których wynikało, że geje przejawiają inne zachowania konsumenckie niż lesbijki. Tylko 39\% lesbijek zadeklarowało wydatki w trakcie wakacji w kwocie powyżej 2500 dol. na osobę $\mathrm{w}$ porównaniu do $64 \%$ gejów $^{11}$. Jak wynika $\mathrm{z}$ badań, $\mathrm{w}$ samym środowisku osób nieheteroseksualnych trudno odnaleźć te same zachowania konsumenckie. To pokazuje, że środowisko to nie jest homogeniczne ${ }^{12}$.

Badania przeprowadzone przez American Economic Association porównują poziom wykształcenia respondentów. Osoby nieheteroseksualne, w tym wypadku geje i lesbijki, są lepiej wykształcone niż osoby heteroseksualne ${ }^{13}$. W badaniach dokonano porównania par heteroseksualnych i jednopłciowych. $\mathrm{Z}$ danych wynika, że w parach gejowskich tylko $6,8 \%$ badanych miało wykształcenie niższe niż szkoła średnia, w parach lesbijskich $-7,7 \%$, natomiast w parach heteroseksualnych - 12,2\% mężczyzn i 10,8\% kobiet. Jeżeli porównamy wyniki związane z wykształceniem co najmniej licencjackim, okazuje się, że 43,2\% gejów ma takie wykształcenie, 42,7\% lesbijek, 27,9\% mężczyzn w związku dwupłciowym oraz $25,6 \%$ kobiet w związku dwupłciowym.

$\mathrm{Z}$ badania wynika, że osoby $\mathrm{z}$ tożsamością nieheteroseksualną są lepiej wykształcone. Może to się przekładać na ich wynagrodzenie oraz pracę, a co za tym idzie - biorąc pod uwagę brak lub małą liczbę dzieci - oznacza więcej środków na bieżącą konsumpcję. Należy jednak w tym miejscu podkreślić inny problem dotyczący osób nieheteroseksualnych, w szczególności gejów. Badania pokazują, że istnieje różnica w płacach pomiędzy osobami nieheteroseksualnymi a heteroseksualnymi. $Z$ badań przeprowadzonych przez Arabsheibani, Marin i Wadsworth wynika, że różnica pomiędzy wynagrodzeniem geja (w związku)

10 G.J. Gates, LGBT Parenting in the United States, http://williamsinstitute.law.ucla.edu/wp-content/uploads/LGBT-Parenting.pdf (dostęp: 28.10.2018).

11 H.L. Hughes, op. cit., s. 60.

12 W opinii autora należy badać całą kategorię społeczną jako jedność. Nie ma wielu badań na temat tej grupy konsumentów, więc trudno ocenić, jaki jest potencjał ekonomiczny poszczególnych podgrup. Najistotniejsze jest jednak podkreślenie tego, że kategoria społeczna osób nieheteroseksualnych nie jest homogeniczna.

13 D.A. Black, S.G. Sanders, L.J. Taylor, The economics of lesbian and gay families, „The Journal of Economic Perspectives" 21, 2007, nr 2, s. 64. 
i mężczyzny heteroseksualnego (w związku) wynosiła 6\% na korzyść osób heteroseksualnych. Procent ten zmieniał się w zależności od poziomu wykształcenia badanych. Co interesujące, porównując zarobki lesbijek i kobiet heteroseksualnych, można zauważyć różnicę w zarobkach - lesbijki (w związku) zarabiają 11\% więcej niż kobiety heteroseksualne (w związku) ${ }^{14}$. Podobne porównanie zostało dokonane przez Black, Sanders, Taylor ${ }^{15}$. Porównali oni średnią godzinową stawkę badanych grup, biorąc pod uwagę wykształcenie respondentów. Jak wynika $\mathrm{z}$ ich badania, geje $\mathrm{z}$ wykształceniem wyższym zarabiają 26,87 dol., w porównaniu do 32,26 dol., które zarabiają mężczyźni heteroseksualni. W przypadku lesbijek były to 22,81 dol. w porównaniu do 22,00 dol. zarabianych przez kobiety heteroseksualne. Tożsamość seksualna może wpływać na różnice w wynagrodzeniu. Niezależnie od tego, że lesbijki zarabiają relatywnie więcej niż kobiety heteroseksualne, ich zarobki nadal są niższe niż mężczyzn. Ze względu na to, że mężczyźni nieheteroseksualni są lepiej wykształceni niż mężczyźni heteroseksualni, niezależnie od niższego wynagrodzenia ich jednostkowy potencjał ekonomiczny jest większy.

Według Community Marketing potencjał ekonomiczny kategorii osób nieheteroseksualnych w Stanach Zjednoczonych wyceniany jest na 790 miliardów dolarów ${ }^{16}$. Należy przy tym zauważyć, że według raportu jest to tylko $4 \%$ do $5 \%$ społeczeństwa. Tego rodzaju siła nabywcza nazywana jest pink dollar, pink pound czy w Polsce - różowe złotówki. W 2015 roku siła nabywcza kategorii osób nieheteroseksualnej w Stanach Zjednoczonych była szacowna na 917 miliardów dolarów - analizy dokonało Witeck Communications ${ }^{17}$. Na podstawie powyższych danych można wnioskować, że kategoria ta generuje duży potencjał rynkowy. Należy jednak pamiętać, że na tych konsumentów mają wpływ różne czynniki.

\section{Strategia gay-friendly jako czynnik determinujący zachowania konsumpcyjne osób nieheteroseksualnych}

Osoby nieheteroseksualne były i często są dyskryminowane ze względu na swoją tożsamość seksualną. Odnosi się to do różnych dziedzin życia - jak już wykazano, istnieją różnice płacowe pomiędzy osobami nieheteroseksualnymi

$14 \mathrm{~K}$. Braun, N. Walter, The myth of the rich and trendy homo-sexual - why gay and lesbians are not overly attractive target segment for marketing, s. 32, https://businesspf.hs-pforzheim.de/fileadmin/user_upload/uploads_redakteur_wirtschaft/Fakultaet_zentral/Dokumente/2013/Turmthesen/ TT_Bd4_04_Braun_Walter.pdf (dostęp: 28.10.2018).

15 Cyt. za: D.A. Black, S.G. Sanders, L.J. Taylor, op. cit., s. 64.

16 Community Marketing \& Insights, LGBT market research. Diversity within the LGBT community, http://communitymarketinginc.com/documents/temp/7th-LGBT-NYC/CMI-LGBT_Research_ Review_Roth.pdf (dostęp: 28.10.2018).

17 Witeck Communications, America's LGBT 2015 Buying Power Estimated at \$917 Billion, https://rivendellmedia.com/assets/LGBT-Buying-Power-2016.pdf (dostęp: 28.10.2018). 
i heteroseksualnymi, jednak takich dziedzin życia społecznego jest dużo więcej. Należałoby wspomnieć o niemożności zawierania związków małżeńskich czy partnerskich, choć w różnych krajach prawa tych osób wyglądają inaczej. W krajach Europy Zachodniej, Ameryki Północnej prawa te są bardzo szerokie, wręcz porównywalne do praw osób heteroseksualnych. Natomiast inne kraje mają przed sobą długą ścieżkę zmian legislacyjnych. Nie w każdym państwie osoba będąca w związku z osobą tej samej płci ma prawo dziedziczyć po partnerze, otrzymywać informacje o stanie jego zdrowia, korzystać z ulg podatkowych, adoptować dziecko. Takich aspektów życia jest wiele. Nie można zbagatelizować sytuacji, w której społeczeństwa lub rządy uważają związki nieheteroseksualne za dewiacje lub też przestępstwo. Jednym z takich krajów jest Rosja, w której homoseksualizm traktowany jest jak zboczenie. W tym miejscu należałoby podkreślić, że Amerykańskie Towarzystwo Psychiatryczne już w 1973 roku wykreśliło homoseksualizm z listy chorób psychicznych.

Ze względu na dyskryminacje, które dotknęły lub dotykają środowiska nieheteroseksualne, konsumenci przejawiają różne zachowania konsumenckie. Po pierwsze, konsument nieheteroseksualny jest wrażliwy na homofobię. Środowiska nieheteroseksualne potrafią powstrzymać się od kupowania danego dobra lub korzystania z konkretnych usług jeżeli okaże się, że firma lub jej zarząd wykazują skłonności homofobiczne. Na polskim rynku można było zaobserwować dwie takie sytuacje. Jeden z nieistniejących już przewoźników — Polskibus — został zbojkotowany przez środowiska nieheteroseksualne, po tym jak jego właściciel udzielił wywiadu, w którym stwierdził, że nie toleruje odmienności seksualnej. Drugim przypadkiem był Browar Ciechan — właściciel browaru w nietolerancyjny sposób wypowiedział się o odmienności seksualnej. Wypowiedzi te wywołały reakcje środowisk nieheteroseksualnych, dochodziło do sytuacji, w których klubokawiarnie ogłaszały rezygnację ze współpracy z browarem ze względu na homofobiczną wypowiedź. Konsumenci byli nawoływani do zaprzestania kupowania produktów tego producenta. Trudno oszacować, jaki skutek przyniósł ten bojkot. Nie da się dokładnie określić, czy sprzedaż danych produktów/usług spadła, czy pozostała na niezmienionym poziomie, a może wzrosła, ponieważ w tym samym czasie środowiska prawicowe i nacjonalistyczne nawoływały do zakupów.

Należy zauważyć, że środowiska nieheteroseksualne potrafią zbudować wspólny front przeciwko osobom czy firmom, które starają się dyskryminować tę kategorię, dla której jedyną cechą wspólną jest tożsamość seksualna. Pisząc o środowiskach nieheteroseksualnych, należy wspomnieć, że wśród nich są również osoby o orientacji heteroseksualnej, określający się jako sprzymierzeńcy osób nieheteroseksualnych. Takie osoby aktywnie włączają się w walkę o równość czy tolerancję. 


\section{Strategia gay-friendly}

Aspekt tolerancji, równości czy wspierania osób nieheteroseksualnych jest istotny dla konsumentów nieheteroseksualnych. W marketingu powstało określenie gay-friendly, które oznacza organizacje/firmy wspierające równość i otwartość. Wsparcie może objawiać się na wiele sposobów — od umieszczenia tęczowej flagi w siedzibie firmy po finansowanie organizacji lobbujących za równością osób nieheteroseksualnych. Samo pojęcie gay-friendly jest definiowane jako nieformalne określenie o miejscu, ludziach czy instytucjach, które są otwarte i przyjaźnie nastawione do ludzi homoseksualnych (włączając wszystkie osoby będące częścią kategorii osób nieheteroseksualnych), aby kreować środowisko, które wspiera osoby nieheteroseksualne i ich relacje, szanuje wszystkich ludzi, traktuje ich równo i nieoceniająco ${ }^{18}$. Tuten definiuje to określenie w następujący sposób: określenie firm, które respektują i walczą o prawa osób nieheteroseksualnych ${ }^{19}$.

Niezależnie od tego, jak zdefiniowane zostanie pojęcie gay-friendly, wyznacznikiem, czy firma jest przyjazna osobom nieheteroseksualnym, jest jej nastawienie do tego środowiska. Należy pamiętać, że firma kierująca się strategią gay-frien$d l y$ musi budować swój wizerunek nie tylko na podstawie działań skierowanych w stronę klientów czy odbiorców, musi ona także godnie traktować swoich pracowników. Oznacza to, że benefity pracownicze oraz warunki pracy muszą być takie same dla wszystkich pracowników, nie można nikogo wykluczyć lub traktować gorzej ze względu na jego tożsamość płciową, seksualną. Należy zauważyć, że określenie to nie jest zarezerwowane wyłącznie dla firm, może być użyte w stosunku do ludzi lub też nawet państw czy miast. Kampanie reklamowe opierające się na strategii gay-friendly były prowadzone przez Niemcy czy Wiedeń. W środowisku osób nieheteroseksualnych istnieją poglądy, że niektóre miasta są bardziej tolerancyjne od innych.

Wdrożenie strategii gay-friendly przynosi firmom wymierne korzyści. Badania GL Census Partners pokazują, że więcej niż osiem na dziesięć osób nieheteroseksualnych woli kupować produkty marek, które kierują się strategią gay-friendly ${ }^{20}$. Dodatkowo blisko połowa respondentów w trakcie podejmowania decyzji o zakupie produktu zastanawia się, czy firma realizuje strategię gay-friendly. Tuten przywołuje w swojej pracy również inne badania, które podkreślają znaczenie strategii w procesie zakupowym osób nieheteroseksualnych ${ }^{21}$.

18 G.W. Oakenfull, What matters: Factors influencing gay consumers' evaluations of "gay-friendly" corporate activites, s. 81, https://www.gayadnetwork.com/files/AMAreport.pdf (dostęp: 28.10.2018).

19 T.L. Tuten, The effect of gay-friendly and non-gay-friendly cues on brand attitudes: A comparison of heterosexual and gay/lesbian reactions, cyt. za: G.W. Oakenfull, op. cit.

20 T.L. Tuten, Exploring the importance of gay-friendliness and its socialization influences, „Journal of Marketing Communications" 12, 2006, nr 2, s. 80.

21 Ibidem. 
Duże znaczenie odnośnie do strategii gay-friendly ma reklama. Zjawisko to zostało zauważone przez marketingowców, którzy kategorię społeczną osób nieheteroseksualnych określili akronimem DINK — doble income and no kids.

Producent wódki Absolut był jedną z firm, które umieszczały reklamy w gejowskich magazynach oraz reklamowały się w trakcie gejowskich imprez. Pierwszą firmą na świecie, która w swojej reklamie telewizyjnej wykorzystała wizerunek pary jednopłciowej, była sieć IKEA. Reklama ta była kierowana do odbiorców w Stanach Zjednoczonych, jej emisja odbyła się w 1994 roku. Należy podkreślić, że rynek już w latach 80 . XX wieku dostrzegł tę niszę, wszystko to za sprawą rewolucji seksualnej.

Tak jak w zachowaniach konsumenckich, tak w podejściu do reklamy widać różnice pomiędzy lesbijkami i gejami. Oakenfull wymienia badania, na podstawie których można wyciągnąć wnioski, że istnieje różne podejście do treści reklamowanych w kategorii społecznej lesbijek i gejów ${ }^{22}$. Geje bardziej wykazują negatywną postawę w stosunku do reklam niż lesbijki. Oceniają reklamy bardziej surowo. Dodatkowo lesbijki są mniej zainteresowane tym, czy osoby nieheteroseksualne są $\mathrm{w}$ tych reklamach pokazywane $\mathrm{w}$ dobrym, zgodnym z rzeczywistością świetle. Badania wykazują po raz kolejny, że środowisko osób nieheteroseksualnych nie jest homogeniczne i znajdują się tam co najmniej dwie różne grupy konsumentów.

W Polsce strategię gay-friendly chciał wdrożyć polski przewoźnik - firma LOT. Została stworzona specjalna strona skierowana do osób nieheteroseksualnych $-\mathrm{z}$ tęczową flagą oraz przewodnikami po miejscach przyjaznych osobom nieheteroseksualnym. W związku z tym, że w Polsce nadal jest wiele osób przejawiających postawy homofobiczne, strona działała w swoim pierwotnym kształcie tylko jeden dzień. Kolejnego dnia ze strony zniknęły wszystkie odniesienia do słów „gej”, „lesbijka”, „LBGT”, pozostała natomiast tęczowa flaga.

W rezultacie firma chcąca się wypromować jako przyjazna osobom nieheteroseksualnym ze względu na naciski stała się firmą, która zamiast sprzymierzyć się ze środowiskiem osób nieheteroseksualnych, zrobiła coś zupełnie odwrotnego.

Strategia gay-friendly otwiera firmom możliwości, których nie miały one wcześniej. Umożliwia ekspansję na nowym rynku zbytu. Dużym ograniczeniem dla firm jest obawa przed negatywnym odbiorem takiej strategii przez osoby heteroseksualne, szczególnie te negatywnie nastawione do środowiska osób nieheteroseksualnych.

W 2018 roku największą kampanią skierowaną do kategorii osób nieheteroseksualnych w Polsce była kampania serwisu internetowego Netflix. Firma ta była sponsorem większości parad równości w Polsce. Dodatkowo w miastach, w których odbyły się parady pod jej patronatem, widniały bilbordy reklamujące serial emitowany na tym portalu - Orange is the new black. Marketingowcy wykorzystali nazwę serialu do reklamowania równości poprzez dodanie na materiałach

22 G.W. Oakenfull, op. cit. 
informacyjnych hasła „Orange is part of the rainbow”. W ten sposób serwis był w stanie wypromować swoją markę oraz produkt, a dodatkowo zwrócić uwagę na potrzebę tolerancji.

Na polskim rynku trudno mówić o wielu firmach, które promują równość. Polską firmą promującą równość - choć nieokreślającą siebie jako gay-friendly - jest producent rajstop Adrian. Firma zaprosiła do swojej kampanii reklamowej pierwszą w Europie posłankę transseksualną Annę Grodzką. Hasło reklamowe kampanii brzmiało: „Adrian... kocha wszystkie kobiety”.

\section{Zakończenie}

Artykuł w syntetyczny sposób przedstawia konsumenta nieheteroseksualnego. Głównym celem było przedstawienie argumentów popierających stanowisko, że taki konsument istnieje i ma swoje miejsce na rynku. Ważne było również określenie potencjałów ekonomicznych płynących z wyodrębniania nowej grupy konsumenckiej.

Kategoria społeczna osób nieheteroseksualnych jest znacząca, ponieważ jej potencjał ekonomiczny jest duży i nie w pełni wykorzystany. Osoby te są lepiej wykształcone niż osoby heteroseksualne. Ważnym aspektem związanym z kategorią osób nieheteroseksualnych jest brak lub mała liczba dzieci w gospodarstwie domowym. Daje to większe możliwości bieżącej lub przyszłej konsumpcji. Niezależnie od wymienionych argumentów przemawiających za dużym potencjałem ekonomicznym należy pamiętać, że zarobki gejów są niższe niż zarobki mężczyzn heteroseksualnych.

Ta grupa konsumentów została dostrzeżona przez firmy w latach 80. XX wieku. Należy jednak podkreślić, że ilość danych zastanych w literaturze polskiej nie jest wystarczająca, żeby dokonać analizy rodzimej grupy konsumentów nieheteroseksualnych. Duże znaczenie dla osób nieheteroseksualnych ma podejście firmy do równości. Dlatego też coraz częściej wdrażana jest strategia określana jako gay-friendly.

Osoby nieheteroseksualne są liczną kategorią społeczną, która może się powiększać - jest to związane z wzrastającą społeczną akceptacją osób nieheteroseksualnych przez społeczeństwo. Może to oznaczać, że coraz więcej osób nie będzie czuło strachu przed określaniem się jako nieheteroseksualne. Tego rodzaju zmiany społeczne mogą przynieść wymierne korzyści dla firm, lecz również dać możliwość lepszego zrozumienia zachowań konsumenckich przedstawionej kategorii społecznej. Oznacza to, że konsument nieheteroseksualny będzie miał coraz większy wpływ na rynek i to, w jaki sposób będzie on funkcjonował w przyszłości. 


\section{Bibliografia}

Bancroft J., Seksualność człowieka, przeł. R. Śmietana Wrocław 2012.

Black D., Sanders S.G., Taylor L.J., The economics of lesbian and gay families, „The Journal of Economic Perspectives" 21, 2007, nr 2.

Braun K., Walter N., The myth of the rich and trendy homo-sexual - why gay and lesbians are not overly attractive target segment for marketing, https://businesspf.hs-pforzheim.de/fileadmin/ user_upload/uploads_redakteur_wirtschaft/Fakultaet_zentral/Dokumente/2013/Turmthesen/ TT_Bd4_04_Braun_Walter.pdf.

Community Marketing \& Insights, LGBT market research. Diversity within the LGBT community, 2014, http://communitymarketinginc.com/documents/temp/7th-LGBT-NYC/CMI-LGBT_Research_Review_Roth.pdf.

Escoffier J., The sexual revolution, 1960-1980, 2004, http://www.glbtqarchive.com/ssh/sexual_ revolution_S.pdf.

Gates G., LGBT parenting in the United States, 2013, http://williamsinstitute.law.ucla.edu/wpcontent/uploads/LGBT-Parenting.pdf.

Hughes H., Pink tourism. Holidays of Gay Man and Lesbians, Wallingford 2006.

Kinsey A., Pomeroy W., Martin C., Sexual Behavior in the Human Male, Philadephia-London 1949.

Oakenfull G., What matters: Factors influencing gay consumers' evaluations of "gay-friendly" corporate activites, 2013, https://www.gayadnetwork.com/files/AMAreport.pdf.

Seidman S., Społeczne tworzenie seksualności, przeł. P. Tomanek Warszawa 2012.

Sell R., Definiowanie i pomiar orientacji seksualnej — przegląd, „Przegląd Badań Edukacyjnych” 2015, nr 21.

Tuten T., Exploring the importance of gay-friendliness and its socialization influences, „Journal of Marketing Communications" 12, 2006, nr 2.

Witeck Communications, America's LGBT 2015 buying power estimated at \$917 billion, 2016, https:// rivendellmedia.com/assets/LGBT-Buying-Power-2016.pdf.

\section{Non-heterosexual people as consumers}

\section{Summary}

The article presents a description of non-heterosexual customers. The author took into consideration aspects of sexuality emerging from the creation of new social groups according to a gay-friendly strategy. The main goal was to show how sexual identity influences customer behaviors. Social exclusion of non-heterosexual people was mentioned as the main cause of the creation of gay or lesbian social groups. The article also presents correct and incorrect examples of the implementation of gay-friendly strategy. 